\title{
Metals in urban soils of Sevilla: seasonal changes and relations with other soil components and plant contents
}

\author{
L. MADRID, E. Díaz-BARRIENTOS, R. REINoSo \& F. MADRID \\ Instituto de Recursos Naturales y Agrobiología de Sevilla (CSIC), Apartado 1052, 41080 Sevilla, Spain
}

\begin{abstract}
Summary
Soils of the urban area of Sevilla have been scarcely studied, especially concerning their concentrations of potentially toxic metals. A previous paper has shown that moderate pollution exists in soils from some public green areas of the city, and a common pattern was found in the distribution of the concentrations of some particular metals. The present paper is aimed at (i) determining possible seasonal changes in the measured concentrations; (ii) checking possible effects of the observed pollution on plant metal contents, and (iii) finding possible relations between metals by statistical techniques.

Samples of 35 soils from the urban area of Sevilla were studied. Comparison with previous data shows that samples from a depth of $0-20 \mathrm{~cm}$ are representative of the measured soil properties for the city. We show that in most cases differences in the EDTA- and aqua regia-extractable metal contents between autumn 2000 and summer 2001 are not significant. Only $Z n$ shows significant decreases $(P<0.05)$, probably because it is more mobile than the other metals studied. Electrical conductivity and $\mathrm{pH}$ also show significant changes related to leaching of soluble salts. We found a strong association between 'urban' metals (as defined in the literature) and organic matter, as shown by factor analysis, whereas 'non-urban' metals could be related to clay and carbonate contents, perhaps coming from the soil parent materials. The behaviour of the urban metals means that organic matter contributes to their accumulation, either by retention of the incoming metals from the atmosphere, dust or various human activities, or from addition of organic amendments that might provide significant amounts of such metals. Although concentrations of $\mathrm{Cu}, \mathrm{Pb}$ and $\mathrm{Zn}$ at several sites exceeded the limits established elsewhere as acceptable in residential areas, the values in the grass were less than those considered as normal in the literature. This implies that fairly large concentrations in the soil do not necessarily make metals more available.
\end{abstract}

\section{Introduction}

Pollution of soil by potentially toxic metals is of ten assessed in terms of total concentrations. However, many forms of metal are strongly held in soil and generally become immobile, although several factors (changes in $\mathrm{pH}$ or redox conditions, soluble organic complexing agents, etc.) may mobilize such forms (Adriano, 1986; Madrid, 1999).

In both agricultural and horticultural soils, the availability of a given metal is crucial, as this determines uptake by food crops and the consequent risk to the food chain. Soils in urban environments receive considerable pollution from industry, traffic, refuse and vandalism, and are easily inhaled or ingested as suspended matter or by direct contact. Here too, depending on the metal, its speciation and its toxicity mechanism, the

Correspondence: L. Madrid. E-mail: madrid@irnase.csic.es most mobile (or soluble) forms are more likely to be harmful than those held strongly in the soil matrix.

The chemistry of pollutants, including metals, in urban soils is far from understood, and several aspects of the dynamics of metal pollutants in urban soils need further study, for example the degree of interaction of contaminants with the soil constituents. In the last few years, soils in many cities have been studied, for example in Salamanca, Valladolid and Madrid (De Miguel etal., 1997, 1998; Sánchez Martín etal., 2000), Aberdeen (Paterson et al., 1996), Athens (Chronopoulos et al., 1997), Kiel (Beyer etal., 1996), and Rostock (Kahle, 2000). After statistical analysis of their data, De Miguel etal. (1997) concluded that metals in urban soil could be divided into three groups according to their source. They defined 'natural' clements ( $\mathrm{Al}, \mathrm{Ga}, \mathrm{Mn}, \mathrm{Y}$, etc.) as those showing concentrations dependent upon the parent material. Elements of anthropogenic origin (from traffic, building, etc.), such as $\mathrm{Ba}, \mathrm{Cu}, \mathrm{Pb}, \mathrm{Zn}$, etc., 


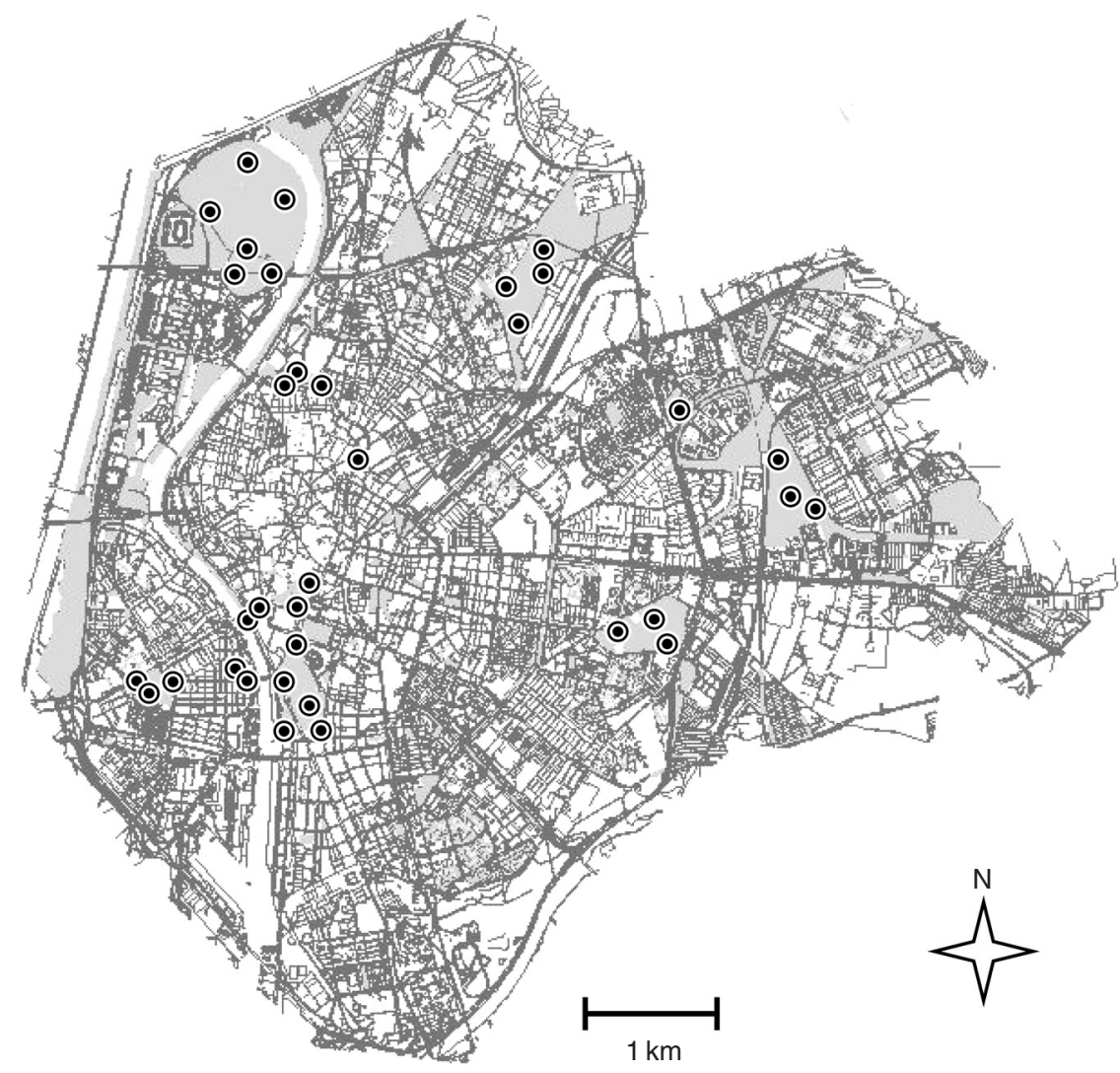

Figure 1 Location of the sampling points within the urban area of Sevilla. were defined as 'urban'. They identified a third group (Ca, Fe, $\mathrm{Ni}$, U, etc.) including both those elements likely to have undergone geochemical changes from their original form and those of mixed origin. Similarly, Birke \& Rauch (2000) suggested that some metals were of natural origin whereas others could be attributed to industry. Mielke et al. (2000) found different degrees of association among metals in urban soils of New Orleans, with $\mathrm{Pb}, \mathrm{Zn}, \mathrm{Cr}$ and $\mathrm{Cu}$ as dominant metals strongly correlated with one another. They also found positive correlations for $\mathrm{Cd}, \mathrm{Mn}, \mathrm{Ni}$ and $\mathrm{V}$, but these differed from the first group in their distribution within the city. In the case of $\mathrm{Pb}$, Mellor \& Bevan (1999) found that in a Tyneside catchment in Great Britain the greatest concentrations of $\mathrm{Pb}$ were in the more urban and industrialized areas.

Recently, a wide survey, URBSOIL, has been initiated in several European cities, including Sevilla, to define the main variables for a comprehensive description of urban soil quality. Madrid et al. (2002) described a preliminary sampling designed to identify the distribution of heavy metals in the city, and their possible relations with the various soil components. Samples of soils were taken from $0-10 \mathrm{~cm}$ and $10-20 \mathrm{~cm}$ depth in September to December 2000, and concentrations of metals extracted by $0.05 \mathrm{M}$ EDTA and aqua regia were determined. Some patterns in their spatial distribution suggested moderate pollution, partly related to traffic density, in several parks and gardens, particularly those closer to the historic centre of the city. At such sites, the concentrations of some metals exceeded the limits established elsewhere as acceptable in residential areas (Moen et al., 1986; Ministère de l'Environnement du Québec, 2001). Marked differences in the EDTA and aqua regia data for $\mathrm{Pb}, \mathrm{Zn}$ and $\mathrm{Cu}$ are attributed to the 'urban' nature of these elements, as concluded by De Miguel et al. (1997) for urban soils in Madrid. Chromium extracted by EDTA also shows a positive relationship with traffic density. This suggests an urban origin for the more available fractions of this metal.

The continuing cycle of construction, use and renewal of urban structures, as well as management and accidental or incidental pollution, lead to far higher rates of change in urban environments than is common elsewhere (Thornton, 1991). To observe any possible seasonal changes due to human activities and to the marked differences in temperature between winter and late spring/early summer in Sevilla, we undertook a new sampling campaign in June and July 2001. Samples of grass were also taken at each sampling point so that we could check whether the metal concentrations in the soil affected those in the plants. In this paper we describe our results and compare them with those of Madrid et al. (2002). 
By combining the data from the two studies we aimed to provide a useful basis for planning and developing the URBSOIL project. Statistical evidence of the different behaviour of the various metals, in relation to their 'urban' or 'natural' origin (as defined by De Miguel et al., 1997), is also given.

\section{Methods}

Thirty-five samples were collected in the main public parks and gardens in Sevilla (Figure 1). Within the larger sites ( $>4$ ha), sampling points were fairly evenly distributed with a density of one per 2-3 ha. The smaller sites $(<4 \mathrm{ha})$ were sampled at one single, central point. Wherever possible the same sites sampled by Madrid et al. (2002) were selected, but some of the sites in the previous study had to be discarded, as they were affected by public works in progress or were inaccessible for other reasons. Additional points were sampled in the main parks to match the chosen density of sampling. For these reasons, only 26 sampling points coincide with points of those sampled earlier. At each point, grass samples (leaves and stems) of Cynodon spp., Paspalum spp. and Lolium spp. were also taken.

A paired $t$-test was applied to data from Madrid et al. (2002) to check the significance of the differences between samples from $0-10 \mathrm{~cm}$ and $10-20 \mathrm{~cm}$ depth. No significant differences between depths were found for most general descriptive variables and the aqua regia- and EDTA-extractable metals $(P>>0.05)$. Only calcium carbonate equivalent (CCE), organic $\mathrm{C}$, available $\mathrm{K}$ and EDTA-extractable $\mathrm{Mn}$ and $\mathrm{Ni}$ showed significant differences between depths $(P<0.05)$. The relations between EDTA-extractable $\mathrm{Cu}, \mathrm{Pb}$ and $\mathrm{Zn}$ for the $0-10 \mathrm{~cm}$ and $10-20 \mathrm{~cm}$ samples and the calculated reduced major axis for the scatter of each metal are shown in Figure 2 as an example. Similar relationships obtained for other metals are not shown here. Slopes close to 1 and small intercepts suggest

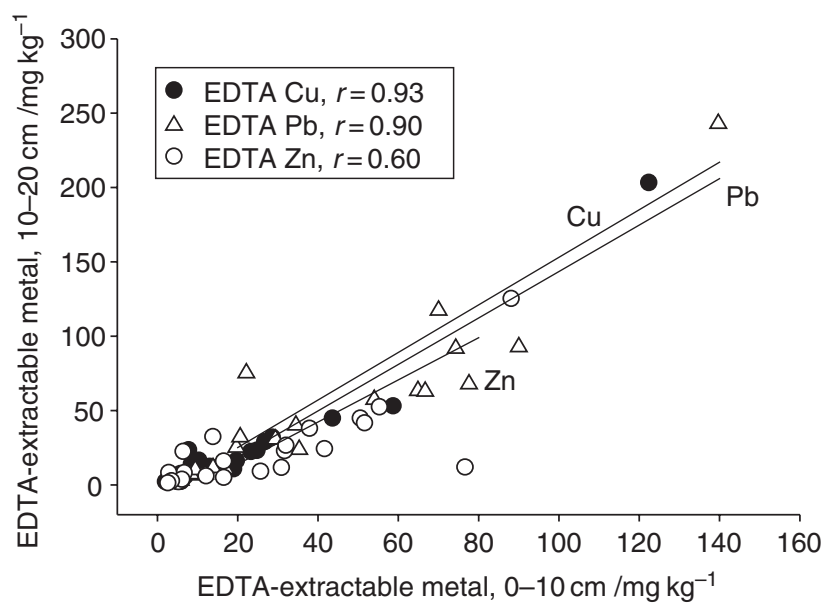

Figure 2 Relationships between EDTA-extractable $\mathrm{Cu}, \mathrm{Pb}$ and $\mathrm{Zn}$ at $0-10 \mathrm{~cm}$ and $10-20 \mathrm{~cm}$ depth. Similar patterns are obtained with other metals (not shown). The straight lines are the reduced major axes. that, on average, the concentrations at the two depths are similar. We therefore consider samples at $0-20 \mathrm{~cm}$ depth to be representative of soil surface metal concentrations. Composite soil samples were taken by mixing three subsamples of about $2 \mathrm{~kg}$ from three random excavations within $1 \mathrm{~m}^{2}$ around each sampling point.

Stones and foreign objects were removed from the samples by hand. The samples were air-dried, gently crushed, and sieved to $<2 \mathrm{~mm}$. A portion of each sample was ground further to $<0.5 \mathrm{~mm}$ for aqua regia digestion. Particle-size distribution was determined by the hydrometer method (Gee \& Bauder, 1986). Soil chemical properties were determined following standard procedures (Page et al., 1982), pH in water $(1: 2.5)$ extract, electrical conductivity in $1: 5$ extract, calcium carbonate equivalent by a manometric method, organic matter by $\mathrm{K}_{2} \mathrm{Cr}_{2} \mathrm{O}_{7}$ oxidation, available $\mathrm{P}$ by extraction with $0.5 \mathrm{M}$ $\mathrm{NaHCO}_{3}$ at pH $8.5(1 \mathrm{~g}: 20 \mathrm{ml})$ and available $\mathrm{K}$ by extraction of $5 \mathrm{~g}$ with $50 \mathrm{ml}$ of $1 \mathrm{M} \mathrm{NH}_{4} \mathrm{CH}_{3} \mathrm{COO}$ at $\mathrm{pH}$. Metals were extracted for 1 hour from $1 \mathrm{~g}$ of soil by $10 \mathrm{ml}$ of $0.05 \mathrm{M}$ EDTA (Ure et al., 1993) and by digestion of $1 \mathrm{~g}$ of soil with $4 \mathrm{ml}$ of aqua regia for 15 minutes in a microwave oven (Kingston \& Haswell, 1997). The former method gives good estimates of the availabilities of heavy metals to plants (Quevauviller etal., 1997; Arambarri et al., 1999). The aqua regia digestion procedure is judged adequate for analysing total recoverable metals in soils (Vercoutere etal., 1995). The residual elements not released by aqua regia are mostly bound to silicate minerals, and are considered unimportant when estimating the mobility and behaviour of the elements (Niskavaara et al., 1997; Chen \& Ma, 2001). The amount extracted by aqua regia is sometimes called the 'pseudo total content', and has been used to assess the risks of direct intake of metals from soil by children and animals (Gupta et al., 1996).

We analysed the grass samples after washing and drying them at $70^{\circ} \mathrm{C}$ for 48 hours, grinding them and then digesting $0.5 \mathrm{~g}$ in $4 \mathrm{ml}$ of concentrated $\mathrm{HNO}_{3}$ for 15 minutes in a microwave oven (Jones \& Case, 1990). The mixtures were then filtered through Whatman No 2 paper, and their volumes were made up to $50 \mathrm{ml}$.

Metal concentrations were determined by ICP-OES. Analytical grade reagents were used throughout, and blank samples were included in each extraction procedure. We used plastic sieves and trays when handling soil samples and avoided stainless steel tools. Quality control was periodically carried out with IRMM reference materials CRM-600 for EDTA extraction, CRM-141R for aqua regia digestion, and CRM-281 for plant digestion. Deviations were within $\pm 10 \%$ of the certified values.

\section{Results and discussion}

\section{Soil data: Comparison with the previous sampling}

Table 1 shows the mean values, medians, standard deviations (SD) and ranges of the data of the general descriptive variables 
Table 1 Means, medians, standard deviations (SD) and ranges for the general descriptive properties of the 35 soil samples

\begin{tabular}{lcccc}
\hline & Mean & Median & SD & Range \\
\hline $\mathrm{pH}$ & 8.0 & 8.0 & 0.13 & $7.6-8.3$ \\
$\mathrm{EC} / \mathrm{dS} \mathrm{m}^{-1 \mathrm{a}}$ & 0.18 & 0.19 & 0.05 & $0.11-0.31$ \\
$\mathrm{CCE} / \mathrm{g} \mathrm{kg}^{-1 \mathrm{~b}}$ & 208 & 220 & 77 & $10-360$ \\
$\mathrm{OC} / \mathrm{g} \mathrm{kg}^{-1 \mathrm{c}}$ & 16.2 & 15.4 & 0.72 & $5.0-30.0$ \\
$\mathrm{~N} / \mathrm{g} \mathrm{kg}^{-1}$ & 1.3 & 1.4 & 0.55 & $0.4-2.5$ \\
Available P $/ \mathrm{mg} \mathrm{kg}^{-1}$ & 32 & 19 & 36 & $2-172$ \\
Available K $/ \mathrm{mg} \mathrm{kg}^{-1}$ & 341 & 291 & 205 & $131-1160$ \\
Coarse sand $/ \mathrm{g} \mathrm{kg}^{-1}$ & 278 & 238 & 150 & $38-577$ \\
Fine sand $/ \mathrm{g} \mathrm{kg}^{-1}$ & 115 & 106 & 62 & $38-359$ \\
Silt $/ \mathrm{g} \mathrm{kg}^{-1}$ & 355 & 350 & 110 & $182-563$ \\
Clay $/ \mathrm{g} \mathrm{kg}^{-1}$ & 251 & 245 & 88 & $95-453$ \\
\hline
\end{tabular}

${ }^{\mathrm{a}}$ Electrical conductivity.

${ }^{\mathrm{b}}$ Calcium carbonate equivalent.

${ }^{\mathrm{c}}$ Organic C.

for the soil samples. Figure 3 shows the particle-size distribution of all samples according to the USDA scheme. Most samples fall into the clay loam, loam or sandy loam classes. The exceptions are haphazardly distributed throughout the city, indicating that soil texture is not related to geographical location. In fact most sites have a common geological origin. Information on urban soils (Bullock \& Gregory, 1991; De Kimpe \& Morel, 2000) suggests that the average contents in Sevilla for organic C and total N (Table 1) were rather small, as were the values for the $\mathrm{C} / \mathrm{N}$ ratio. The mean organic $\mathrm{C}$ and total $\mathrm{N}$ values were $20 \%$ and $30 \%$ less than in the first sampling, 20 and $1.9 \mathrm{~g} \mathrm{~kg}^{-1}$, respectively (averages of the two depths studied by Madrid etal., 2002), but the differences are not significant (see Table 3).

Table 2 shows the means, medians, SD, ranges and skewness for the metals extracted by EDTA and aqua regia. The SD of the log-transformed data are also given. The metal data summarized in Table 2 are similar to those from the earlier study. In most cases, the ranges show a rather large dispersion of the data, although somewhat smaller in the case of Mn, Ni and Fe. Many metals have positively skewed distributions, except EDTA $\mathrm{Cr}$ and aqua regia $\mathrm{Cr}$, $\mathrm{Ni}$ and $\mathrm{Fe}$. However, only $\mathrm{Cu}$, $\mathrm{Pb}$ and $\mathrm{Zn}$ extracted by both methods showed medians considerably smaller than the means. When data are logtransformed, the SD for these three metals and for EDTA Cr are noticeably larger than those for aqua regia $\mathrm{Cr}$ or for $\mathrm{Mn}$, $\mathrm{Ni}$ or Fe by both methods. Large relative SD, both for the raw and for the log-transformed data, together with the large ranges and skewness coefficients observed in the data for $\mathrm{Cu}$, $\mathrm{Pb}$ and $\mathrm{Zn}$ must be a consequence of the large concentrations found at several sampling points. In fact, as found previously, in many cases the aqua regia concentrations of $\mathrm{Cu}, \mathrm{Pb}$ and $\mathrm{Zn}$ exceeded the values established in several countries as 'background' concentrations in soils for non-agricultural uses
1: Clay

2: Silty clay

3: Silty clay loam

4: Sandy clay

5: Sandy clay loam

6: Clay loam

7: Silt

8: Silt loam

9: Loam

10: Sand

11: Loamy sand

12: Sandy loam

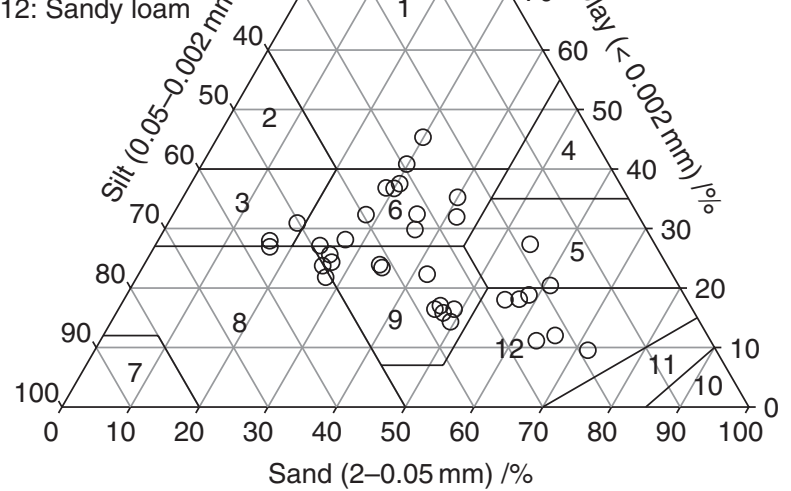

Figure 3 Particle-size distribution of all samples.

(called level A by Moen etal., 1986; and Ministère de l'Environnement du Québec, 2001). Within these cases, several sites had concentrations greater than the maximum acceptable values for recreational areas (level B in those references), and in some places the concentrations of the three metals were greater than the acceptable limits for commercial or industrial areas (level C). As for the first sampling, the largest contents of $\mathrm{Cu}, \mathrm{Zn}$ and $\mathrm{Pb}$ were found in the older green areas, within the inner, historic quarters of the city. Those historic quarters traditionally supported the most intense urban activity and traffic until about 12 years ago. Since then, new outer highways have been built and some of the existing roads have been widened, so that intense urban activity and large traffic densities are now widespread throughout the city and less limited to the centre. The geographical distribution of the metal concentrations (not shown here) is similar to that found by Madrid etal. (2002). The concentrations of the other metals we studied are all less than the acceptable maxima.

To give a more detailed view of possible seasonal changes between the samplings, a paired $t$-test was applied to the data for the 26 points common to both. Table 3 summarizes the results of the test. There are significant differences $(P<0.05)$ between samplings for $\mathrm{Zn}$ extracted by the two methods, and highly significant differences $(P<0.01)$ were found for conductivity, $\mathrm{pH}$, and $\mathrm{Mn}$ and $\mathrm{Fe}$ extracted by EDTA. The decrease in $\mathrm{Zn}$ extracted by both methods suggests that some of this metal was removed by rain or irrigation in winter and spring of 2000-2001. Similarly, changes in electrical conductivity and $\mathrm{pH}$ are probably related to the leaching of soluble salts for the same reason. The highly significant differences for EDTA $\mathrm{Mn}$ and $\mathrm{Fe}$ are not easily explained. The possibility 
Table 2 Means, medians, standard deviations (SD), ranges and skewness coefficients for metal concentrations extractable by EDTA and aqua regia for the 35 soil samples, and SD of the log-transformed data

\begin{tabular}{|c|c|c|c|c|c|c|c|c|}
\hline Extractant & Metal & Mean & $/ \mathrm{mg} \mathrm{kg}^{-1}$ & Median & SD & $\begin{array}{l}\text { Range } \\
/ \mathrm{mg} \mathrm{kg}^{-1}\end{array}$ & $\begin{array}{l}\text { Skewness } \\
\text { coefficient }\end{array}$ & $\begin{array}{l}\text { SD of log- } \\
\text { transformed }\end{array}$ \\
\hline \multirow[t]{7}{*}{ EDTA } & $\mathrm{Cr}$ & 0.118 & & 0.120 & 0.104 & $0.01-0.39$ & 0.8 & 0.56 \\
\hline & $\mathrm{Cu}$ & 16.7 & & 7.63 & 24.7 & $2.2-128$ & 3.3 & 0.46 \\
\hline & $\mathrm{Pb}$ & 39.6 & & 24.0 & 42.2 & $5.6-198$ & 2.1 & 0.43 \\
\hline & $\mathrm{Zn}$ & 16.7 & & 10.6 & 20.0 & $1.3-102$ & 2.7 & 0.49 \\
\hline & $\mathrm{Mn}$ & 47.7 & & 42.3 & 30.4 & $18.5-202$ & 4.1 & 0.18 \\
\hline & $\mathrm{Ni}$ & 0.611 & & 0.540 & 0.41 & $0.16-2.63$ & 3.7 & 0.20 \\
\hline & $\mathrm{Fe}$ & 69.3 & & 66.6 & 24.3 & $32.4-149$ & 1.9 & 0.14 \\
\hline \multirow[t]{7}{*}{ Aqua regia } & $\mathrm{Cr}$ & 42.8 & & 42.0 & 8.8 & $23.7-67.3$ & 0.4 & 0.09 \\
\hline & $\mathrm{Cu}$ & 64.6 & & 41.7 & 74.8 & $11.4-374$ & 2.8 & 0.35 \\
\hline & $\mathrm{Pb}$ & 161 & & 103 & 184 & $14.1-791$ & 2.0 & 0.47 \\
\hline & $\mathrm{Zn}$ & 107 & & 86 & 82 & $25.8-450$ & 2.6 & 0.30 \\
\hline & $\mathrm{Mn}$ & 480 & & 468 & 108 & $335-893$ & 1.9 & 0.09 \\
\hline & $\mathrm{Ni}$ & 23.5 & & 23.1 & 4.1 & $16.4-32.3$ & 0.1 & 0.08 \\
\hline & $\mathrm{Fe}$ & 21000 & & 20900 & 2790 & $14450-27100$ & 0.1 & 0.06 \\
\hline
\end{tabular}

that they are an effect of redox processes (caused by changes in water contents of the soils from winter to summer) seems unlikely, as changes in the metals occur in opposite directions, as shown by the signs for $t$ in Table 3 .

\section{Soil data: Rotated principal component analysis}

Madrid et al. (2002) suggested that $\mathrm{Cu}, \mathrm{Pb}$ and $\mathrm{Zn}$ extracted by either method behaved differently from the other metals. To determine whether a similar distinction can be applied to the new data, we used Varimax-rotated principal component analysis to reveal possible associations among variables. As mentioned above, many metal concentrations (marked in the first column of Table 4) showed a significant skewness, and they were transformed to logarithms for the analysis.

The results are summarized in Table 4, in which the more important contributions of the variables, represented by the correlation coefficients for the first four rotated factors, are shown in bold. The eigenvalues and per cent of variance accounted for by each factor are also shown. About 78.6\% of the total variance was accounted for. A strong association was found between both EDTA- and aqua regia-extractable $\mathrm{Cu}, \mathrm{Pb}$ and $\mathrm{Zn}$ and organic $\mathrm{C}$ content in Factor 1, whereas the clay content was associated with aqua regia-extractable $\mathrm{Cr}$, $\mathrm{Mn}, \mathrm{Ni}$ and Fe. The EDTA contents of Mn, Ni and Fe showed a separate negative association with calcium carbonate equivalent, $\mathrm{CCE}$, in Factor 3. EDTA-extractable $\mathrm{Cr}$ does not show a marked association with any factor, and $\mathrm{pH}$ is isolated in Factor 4. A large proportion of the variance of most variables was accounted for by the factor analysis, so that only CCE, EDTA $\mathrm{Cr}$ and aqua regia $\mathrm{Mn}$ showed communalities with values less than 0.6 , which means that less than $60 \%$ of their
Table 3 Paired $t$-test for the comparison between two samplings (2000 and 2001). Those cases showing $P<0.05$ are printed in bold

\begin{tabular}{|c|c|c|}
\hline Analyte & Student's $t$ & $P$ \\
\hline $\mathrm{EC}^{\mathrm{a}}$ & -3.042 & 0.005 \\
\hline $\mathrm{pH}$ & 5.981 & 0.000 \\
\hline $\mathrm{CCE}^{\mathrm{b}}$ & 1.269 & 0.216 \\
\hline $\mathrm{OC}^{\mathrm{c}}$ & -0.494 & 0.625 \\
\hline Coarse sand & 1.305 & 0.204 \\
\hline Fine sand & -0.982 & 0.335 \\
\hline Silt & -0.658 & 0.516 \\
\hline Clay & -0.419 & 0.679 \\
\hline Total N & -1.802 & 0.084 \\
\hline Available P & -1.212 & 0.237 \\
\hline Available K & 1.885 & 0.071 \\
\hline EDTA Cr & -2.045 & 0.052 \\
\hline EDTA Cu & -1.590 & 0.124 \\
\hline EDTA Pb & 0.207 & 0.838 \\
\hline EDTA Zn & -2.134 & 0.043 \\
\hline Aqua regia $\mathrm{Cr}$ & 1.397 & 0.175 \\
\hline Aqua regia $\mathrm{Cu}$ & -1.069 & 0.295 \\
\hline Aqua regia $\mathrm{Pb}$ & -0.095 & 0.925 \\
\hline Aqua regia $\mathrm{Zn}$ & -2.619 & 0.015 \\
\hline EDTA Mn & -3.068 & 0.005 \\
\hline EDTA Ni & 0.075 & 0.941 \\
\hline EDTA Fe & 3.083 & 0.005 \\
\hline Aqua regia $\mathrm{Mn}$ & -1.034 & 0.311 \\
\hline Aqua regia $\mathrm{Ni}$ & 0.455 & 0.653 \\
\hline Aqua regia $\mathrm{Fe}$ & 0.269 & 0.790 \\
\hline
\end{tabular}

\footnotetext{
${ }^{a}$ Electrical conductivity.

${ }^{\mathrm{b}}$ Calcium carbonate equivalent.

corganic C.
} 
Table 4 Correlation coefficients between extracted metals, organic C, clay and CCE contents, and pH and the first four factors of the analysis, and eigenvalues and per cent of variance accounted for. Components with absolute values $\geq 0.6$ are printed in bold. Communalities show the proportion of each variable variance accounted for by the factors

\begin{tabular}{|c|c|c|c|c|c|}
\hline Variables & Factor 1 & Factor 2 & Factor 3 & Factor 4 & Communalities \\
\hline $\mathrm{OC}^{\mathrm{a}}$ & 0.845 & 0.104 & -0.011 & -0.102 & 0.736 \\
\hline Clay & -0.379 & 0.767 & 0.090 & -0.334 & 0.851 \\
\hline $\mathrm{CCE}^{\mathrm{b}}$ & 0.388 & -0.153 & -0.600 & -0.164 & 0.539 \\
\hline EDTA $\mathrm{Cu}^{\mathrm{c}}$ & 0.969 & -0.012 & 0.087 & 0.022 & 0.948 \\
\hline Aqua regia $\mathrm{Cu}^{\mathrm{c}}$ & 0.962 & 0.020 & -0.103 & 0.014 & 0.937 \\
\hline EDTA $\mathrm{Pb}^{\mathrm{c}}$ & 0.975 & 0.030 & -0.035 & -0.035 & 0.953 \\
\hline Aqua regia $\mathrm{Pb}^{\mathrm{c}}$ & 0.905 & 0.122 & -0.143 & -0.009 & 0.855 \\
\hline EDTA $\mathrm{Zn}^{\mathrm{c}}$ & 0.941 & 0.031 & -0.025 & 0.171 & 0.917 \\
\hline Aqua regia $\mathrm{Zn}^{\mathrm{c}}$ & 0.963 & 0.066 & -0.120 & 0.098 & 0.955 \\
\hline EDTA Cr & 0.018 & 0.524 & -0.045 & 0.207 & 0.320 \\
\hline Aqua regia $\mathrm{Cr}$ & 0.086 & 0.883 & 0.135 & 0.168 & 0.833 \\
\hline EDTA $\mathrm{Mn}^{\mathrm{c}}$ & -0.401 & -0.084 & 0.777 & -0.107 & 0.782 \\
\hline Aqua regia $\mathrm{Mn}^{\mathrm{c}}$ & 0.040 & 0.600 & 0.380 & -0.227 & 0.539 \\
\hline EDTA $\mathrm{Ni}^{\mathrm{c}}$ & 0.073 & 0.056 & 0.930 & -0.173 & 0.904 \\
\hline Aqua regia $\mathrm{Ni}$ & 0.074 & 0.891 & 0.004 & 0.064 & 0.804 \\
\hline EDTA $\mathrm{Fe}^{\mathrm{c}}$ & 0.375 & 0.125 & 0.645 & 0.353 & 0.697 \\
\hline Aqua regia $\mathrm{Fe}$ & 0.427 & 0.720 & -0.082 & 0.045 & 0.709 \\
\hline $\mathrm{pH}$ & -0.014 & 0.133 & -0.023 & 0.910 & 0.847 \\
\hline Eigenvalue & 6.96 & 3.40 & 2.46 & 1.31 & \\
\hline Per cent variance & 39.7 & 18.9 & 13.7 & 7.3 & \\
\hline Cumulative percentage & 39.7 & 57.6 & 71.3 & 78.6 & \\
\hline
\end{tabular}

${ }^{\mathrm{a} O r g a n i c} \mathrm{C}$.

${ }^{\mathrm{b}}$ Calcium carbonate equivalent.

${ }^{\mathrm{c}}$ These variables were $\log _{10}$-transformed to obtain an approximate normal distribution.

variance was accounted for. Inclusion of other soil variables in the analysis did not cause any further improvements in the results. Figure $4(a, b)$ shows the measured variables plotted in the unit circle as their correlation coefficients between them and (a) the first two factors and (b) the first and third factors. The association between the concentrations of the three urban metals and organic $\mathrm{C}$ is clearly suggested by the position of the corresponding points close to the Factor 1 axis far from the origin in both figures. The different behaviours of the aqua regia and EDTA data for $\mathrm{Cr}, \mathrm{Mn}, \mathrm{Ni}$ and $\mathrm{Fe}$ are also evident from their positions.

Thus our analysis shows strong relations between $\mathrm{Cu}, \mathrm{Pb}$ and $\mathrm{Zn}$. In contrast, the concentrations of other metals, namely $\mathrm{Cr}, \mathrm{Mn}$, Ni and $\mathrm{Fe}$, showed clearly different patterns. There are several possible explanations for the association of the 'urban' metals with organic matter. First, some organic amendments, especially those derived from urban wastes, sewage sludge, etc., can have large concentrations of metals. Second, organic matter helps to retain metals that enter the soil (McBride, 1989). As there are no records of waste materials added to these soils and there are no early studies of metal contamination, the first possibility cannot be excluded. Both explanations are therefore plausible in the present case. The association of the other metals, especially their aqua regia contents, with the clay fraction cannot be attributed simply to sorption on materials with a large surface area, as such an association is not found for the urban metals. The opposite signs of the association of EDTA-extractable $\mathrm{Mn}, \mathrm{Ni}$ or $\mathrm{Fe}$ and carbonate contents in Factor 3 exclude co-precipitation as a reason for the association between these variables. Thus a genetic relation of these metals with the original soil materials is possible.

\section{Plant data}

Table 5 lists the mean values, medians, standard deviations and ranges of the metal concentrations for the grass samples taken at each sampling point. The contents of $\mathrm{Pb}$ were very small, erratic, and clearly less than the value for the reference material CRM-281 (2.38 $\left.\mathrm{mg} \mathrm{kg}^{-1}\right)$, and thus probably within the experimental errors of the analysis. We therefore exclude $\mathrm{Pb}$ from this discussion. The strong variation observed for the other 'urban' elements in the soil samples was not found in the plants (compare Tables 2 and 5). In fact the ratios standard deviation/mean for $\mathrm{Cu}$ and $\mathrm{Zn}$ in the plants were comparable 

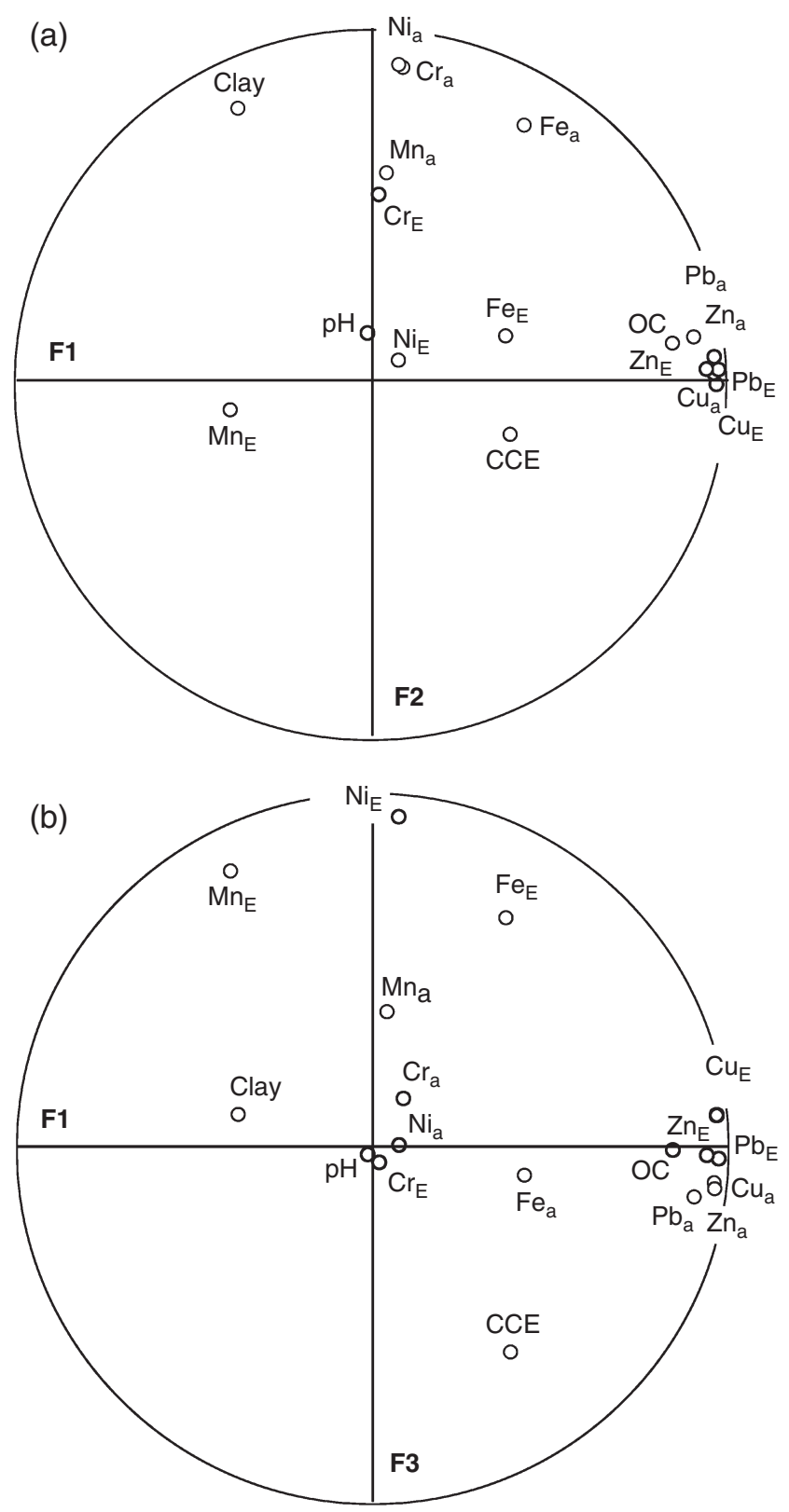

Figure 4 Scatter of the metal contents and some soil properties in the unit circle for (a) the first two factors and (b) the first and third factors. Coordinates are correlation coefficients after Varimax rotation. Subscript ' $E$ ' is metal extracted by EDTA. Subscript ' $a$ ' is metal extracted by aqua regia.

to those for $\mathrm{Cr}, \mathrm{Mn}, \mathrm{Ni}$ and $\mathrm{Fe}$ and those found in the soils for the latter group of metals.

The relations between the metal contents of soil and plant were expressed by determining the correlation for each metal between the EDTA or aqua regia soil contents and the plant data. Table 6 shows the coefficients and significance of each correlation. The $\mathrm{Cu}$ and $\mathrm{Zn}$ contents in the grass samples were significantly related to the EDTA- and aqua regia-extractable
Table 5 Mean values, medians, standard deviations (SD) and ranges for metal concentrations in the grass samples

\begin{tabular}{|c|c|c|c|c|}
\hline \multirow[b]{2}{*}{ Metal } & Mean & Median & \multirow[b]{2}{*}{ SD } & \multirow{2}{*}{$\begin{array}{c}\text { Range } \\
/ \mathrm{mg} \mathrm{kg}^{-1}\end{array}$} \\
\hline & -1 & -1 & & \\
\hline $\mathrm{Cr}$ & 3.49 & 3.59 & 1.57 & $0.30-6.89$ \\
\hline $\mathrm{Cu}$ & 9.99 & 10.3 & 2.40 & $6.69-16.6$ \\
\hline $\mathrm{Zn}$ & 54.5 & 51.3 & 19.0 & $27.5-99.7$ \\
\hline $\mathrm{Mn}$ & 53.7 & 44.5 & 24.0 & $15.1-109$ \\
\hline $\mathrm{Ni}$ & 2.10 & 2.02 & 0.84 & $0.37-4.17$ \\
\hline $\mathrm{Fe}$ & 135 & 121 & 58 & $68.0-340$ \\
\hline
\end{tabular}

concentrations in the soil. In contrast, the elements of 'natural' origin show no relation. Despite the significant relation between the concentrations of urban metals in soils and grass, in those sites with relatively large metal concentrations (Madrid et al., 2002) the plants did not show especially large concentrations. Thus the means in Table 5 are comparable to the concentrations reported for wild weeds in unpolluted areas in Europe (Bargagli, 1998), and to those considered as normal in plants (Greger, 1999). By factor analysis including the plant data (Table 7) we concluded that associations between the plant data and any soil variable are weak or do not exist. Only plant $\mathrm{Mn}$ is negatively related with the urban metals in Factor 1.

\section{Conclusions}

Comparison of our two surveys shows that a sampling depth of $0-20 \mathrm{~cm}$ is suitable for the study of the urban soils of Sevilla. However, sampling to a shallower depth might be more suitable for other urban areas with different soil characteristics, which cause more variation of metals with depth. Variation of the results from autumn to summer was not significant, except for easily leached soil components. The largest concentrations of $\mathrm{Cu}, \mathrm{Pb}$ and $\mathrm{Zn}$ are found in the sites closest to the historic quarters of the city, suggesting a relation with human activities. Accumulation of these metals, which are some of the so-called urban metals, in the soils studied is clearly favoured by organic matter. Other metals are much more uniform in content, probably coming from the parent materials of the soils.

Although fairly large concentrations of the urban metals were found at some sites, the availability of these metals for plants does not seem significant, considering there is little effect on their contents in grass. However, this does not exclude the possibility that they are transferred to humans through ingestion or by inhaling as suspended matter. There is no information about the nature and quality of organic amendments used on these soils in the past. However, the fairly large concentrations at some sites lead us to suggest that care should be taken not to apply any further amendments contaminated with metals. 
Arambarri, I., García, R. \& Millán, E. 1999. Relationships between metal contents in soil and grass contaminated by different anthropogenic sources. Toxicological and Environmental Chemistry, 72, 221-231.

Bargagli, R. 1998. Trace Elements in Terrestrial Plants: An Ecophysiological Approach to Biomonitoring and Biorecovery. Springer-Verlag, Berlin.

Beyer, L., Cordsen, E., Blume, H.-P., Schleuss, U., Vogt, B. \& Wu, Q. 1996. Soil organic matter composition in urbic anthrosols in the city of Kiel, NW Germany, as revealed by wet chemistry and CPMAS ${ }^{13} \mathrm{C}-\mathrm{NMR}$ spectroscopy of whole soil samples. Soil Technology, $\mathbf{9}$, 121-132.

Birke, M. \& Rauch, U. 2000. Urban geochemistry: investigation in the Berlin metropolitan area. Environmental Geochemistry and Health, 22, 233-248.

Bullock, P. \& Gregory, P.J. (eds) 1991. Soils in the Urban Environment. Blackwell Scientific Publications, Oxford.

Chen, M. \& Ma, L.Q. 2001. Comparison of three aqua regia digestion methods for twenty Florida soils. Soil Science Society of America Journal, 65, 491-499.

Chronopoulos, J., Haidouti, C., Chonopoulou-Sereli, A. \& Massas, I. 1997. Variations in plant and soil lead and cadmium content in urban parks in Athens, Greece. Science of the Total Environment, 196, 91-98.

De Kimpe, C.R. \& Morel, J.-L. 2000. Urban soil management: a growing concern. Soil Science, 165, 31-40.

De Miguel, E., Llamas, J.F., Chacón, E., Berg, T., Larssen, S., Royset, O. \& Vadset, M. 1997. Origin and patterns of distribution of trace elements in street dust: unleaded petrol and urban lead. Atmospheric Environment, 31, 2733-2740.

De Miguel, E., Jiménez de Grado, M., Llamas, J.F., MartínDorado, A. \& Mazadiego, L.F. 1998. The overlooked contribution of compost application to the trace element load in the urban soil of Madrid (Spain). Science of the Total Environment, 215, 113-122.

Gee, G.W. \& Bauder, J.W. 1986. Particle-size analysis. In: Methods of Soil Analysis: Part 1, Physical and Mineralogical Methods (ed. A. Klute), pp. 383-411. Agronomy Series No 9, American Society of Agronomy, Madison, WI.

Greger, M. 1999. Metal availability and bioconcentration in plants. In: Heavy Metals Stress in Plants: From Molecules to Ecosystems (eds M.N.V. Prasad \& J. Hagemeyer), pp. 1-23. Springer-Verlag, Berlin.

Gupta, S.K., Vollmer, M.K. \& Krebs, R. 1996. The importance of mobile, mobilisable and pseudo total heavy metal fractions in soil for three-level risk assessment and risk management. Science of the Total Environment, 178, 11-20.

Jones, J.B. \& Case, V.W. 1990. Sampling, handling, and analyzing plant tissue samples. In: Soil Testing and Plant Analysis (ed. R.L. Westerman), pp. 389-427. Soil Science Society of America, Madison, WI.

Kahle, P. 2000. Schwermetallstatus Rostocker Gartenböden. Journal of Plant Nutrition and Soil Science, 163, 191-196.

Kingston, H.M. \& Haswell, S.J. 1997. Microwave-enhanced Chemistry. American Chemical Society, Washington, DC.

Madrid, L. 1999. Metal retention and mobility as influenced by some organic residues added to soils: a case study. In: Fate and Transport of Heavy Metals in the Vadose Zone (eds H.M. Selim \& I.K. Iskandar), pp. 201-223. CRC Press, Boca Raton, FL.
Madrid, L., Díaz-Barrientos, E. \& Madrid, F. 2002. Distribution of heavy metal contents of urban soils in parks of Seville. Chemosphere, 49, 1301-1308.

McBride, M.B. 1989. Reactions controlling heavy metal solubility in soils. Advances in Soil Science, 10, 1-56.

Mellor, A. \& Bevan, J.R. 1999. Lead in the soils and stream sediments of an urban catchment in Tyneside, UK. Water, Air, and Soil Pollution, 112, 327-348.

Mielke, H.W., Gonzales, C.R., Smith, M.K. \& Mielke, P.W. 2000. Quantities and associations of lead, zinc, cadmium, manganese, chromium, nickel, vanadium, and copper in fresh Mississippi delta alluvium and New Orleans alluvial soils. Science of the Total Environment, 246, 249-259.

Ministère de l'Environnement du Québec 2001. Politique de Protection des Sols et de Réhabilitation des Terrains Contaminés. Publications of the MEQ, Collection Terrains Contaminés, Québec.

Moen, J.E.T., Cornet, J.P. \& Evers, C.W.A. 1986. Soil protection and remedial actions: criteria for decision making and standardisation of requirements. In: Contaminated Soil (eds J.W. Assink \& W.J. Brink), pp. 441-448. Martinus-Nijhoff, Dordrecht.

Niskavaara, H., Reimann, C., Chekushin, V. \& Kashulina, G. 1997. Seasonal variability of total easily leachable element contents in topsoils $(0-5 \mathrm{~cm})$ from eight catchments in the European arctic (Finland, Norway, and Russia). Environmental Pollution, 96, 261-274.

Page, A.L., Miller, R.H. \& Keeney, D.R. (eds) 1982. Methods of Soil Analysis: Part 2, Chemical and Microbiological Properties. Agronomy Series No 9, American Society of Agronomy, Madison, WI.

Paterson, E., Sanka, M. \& Clark, L. 1996. Urban soils as pollutant sinks - a case study from Aberdeen, Scotland. Applied Geochemistry, 11, 129-131.

Quevauviller, P., Lachica, M., Barahona, E., Rauret, G., Ure, A., Gómez, A. \& Muntau, H. 1997. The certification of the EDTAextractable contents (mass fractions) of $\mathrm{Cd}$ and $\mathrm{Ni}$ in calcareous soil by the extraction procedures given. BCR Report EUR-17555EN, European Commission, Brussels.

Sánchez Martín, M.J., Sánchez Camazano, M. \& Lorenzo, L.F. 2000. Cadmium and lead contents in suburban and urban soils from two medium-sized cities of Spain: influence of traffic intensity. Bulletin of Environmental Contamination and Toxicology, 64, 250-257.

Thornton, I. 1991. Metal contamination in soils in urban areas. In: Soils in the Urban Environment (eds P. Bullock \& P.J. Gregory), pp. 47-75. Blackwell Scientific Publications, Oxford.

Ure, A.M., Quevauviller, P., Muntau, H. \& Griepink, K.B. 1993. Speciation of heavy metals in soils and sediments: an account of the improvement and harmonization of extraction techniques undertaken under the auspices of the BCR of the Commission of the European Communities. Intern. Journal of Environmental Analytical Chemistry, 51, 135-151.

Vercoutere, K., Fortunati, U., Muntau, H., Griepink, B. \& Maier, E.A. 1995. The certified reference materials CRM 142R light sandy soil, CRM 143R sewage sludge amended soil and CRM 145R sewage sludge for quality control in monitoring environmental and soil pollution. Fresenius Journal of Analytical Chemistry, 352, 197-202. 